METALLURGY AND FOUNDRY ENGINEERING - Vol. 34, 2008, No. 1

Kazimierz Bielenin**, Ireneusz Suliga*

\title{
THE ANCIENT SLAG-PIT FURNACE AND THE REDUCTION PROCESS \\ IN THE LIGHT OF A NEW ARCHAEOLOGICAL CONCEPT AND METALLURGICAL RESEARCH
}

\section{THE STATE OF ARCHAEOLOGICAL RESEARCH INTO THE SLAG-PIT FURNACE IN THE SECOND PART OF THE PREVIOUS CENTURY}

The bloomery furnace, which was typical of Central and Northern Europe in the La Tène culture and in the period of Roman influence, as well as the iron smelting process became of interest to Polish researchers in 1955. The works of Mieczyslaw Radwan such as "Ziemia" ["Earth"] and "Hutnik" ["Ironworker"] published in 1936 and 1937 respectively show the state of the knowledge at the time. The first of these works does not seem to present the complexity of the metallurgical process which took place at the foot of the Świętokrzyskie Mountains. He wrote, "metal sponge saturated with slag gathered at the bottom, under a layer of slag"[1]. In his second work he presented a view that "metallurgical operations were not complex. It was necessary to dig up a pit in the ground, which was then sometimes covered in clay. Then fire was lit and when it was strong enough the pit was filled with powdered ore. A natural draft was used and that is why the pits were dug up on the slopes. Perhaps hand bellows were used. Metal sponge saturated in slag gathered under the lower layer of slag"[2].

This Polish metallurgist was not the only one to think that. German researchers, who in 1907 analyzed different aspects of bloomery furnace stations with slag blocks in Silesian Tarchalice, claimed that metallic iron should gather at the bottom of the furnace. They could not imagine a different way of smelting iron. A similar view was presented by a Czech archaeologist J.A. Jira [3].

* Ph.D., Faculty of Metals Engineering and Computer Sciences for Industry, AGH University of Science and Technology, Kraków, Poland; suliga@tempus.metal.agh.edu.pl

** Prof. Ph.D. D.Sc., Archaeological Museum, Kraków, Poland 
The above mentioned excerpts prove that the generation of contemporary metallurgists that were educated in the spirit of the blast furnace technology did not even suspect that the iron smelting technology in the ancient times could be quite different. The technology used by an ancient smelter consisted in obtaining directly good malleable iron [4-5].

The issues connected to the history of iron making were not given appropriate attention by archaeological researchers after WWII. Metallurgy and what is more the bloomery process were being overlooked by archaeologists. As a result, the bloomery smelting furnace of the pit type was not investigated despite the discoveries of pits filled with slag or entire slag blocks not only in Silesia but also in other regions of Central and Northern Europe.

Systematic archaeological research into ancient iron slag in the Świętokrzyskie Mountains was initiated by the Archaeological Museum in Kraków in 1955. The research was coordinated by Zespół Historii Polskiej Techniki Hutniczej i Odlewniczej [the team investigating the history of Polish metallurgical and casting technology] within the Department of the History of Science and Technology at PAN [Polish Academy of Sciences]. Thanks to the cooperation between archaeologists and metallurgists considerable progress in this field was made in Poland in comparison to other countries [6-8]. The pioneers included the above mentioned M. Radwan and the co-author of this article and archaeologist K. Bielenin. Their research helped to depict the preserved state of slag stations. At the time 116 stations were analyzed, including 26 so called "disorganized" ones which had from 2 to 25 pits. The remaining "organized" stations with 1 or 2 drafts and from 30 pits in Jawor Solecki to 23 pits in Świętomarzy. In the course of research archaeologists encountered a furnace in Rudki whose pits and slag blocks were undamaged (Fig. 1) [9-10].

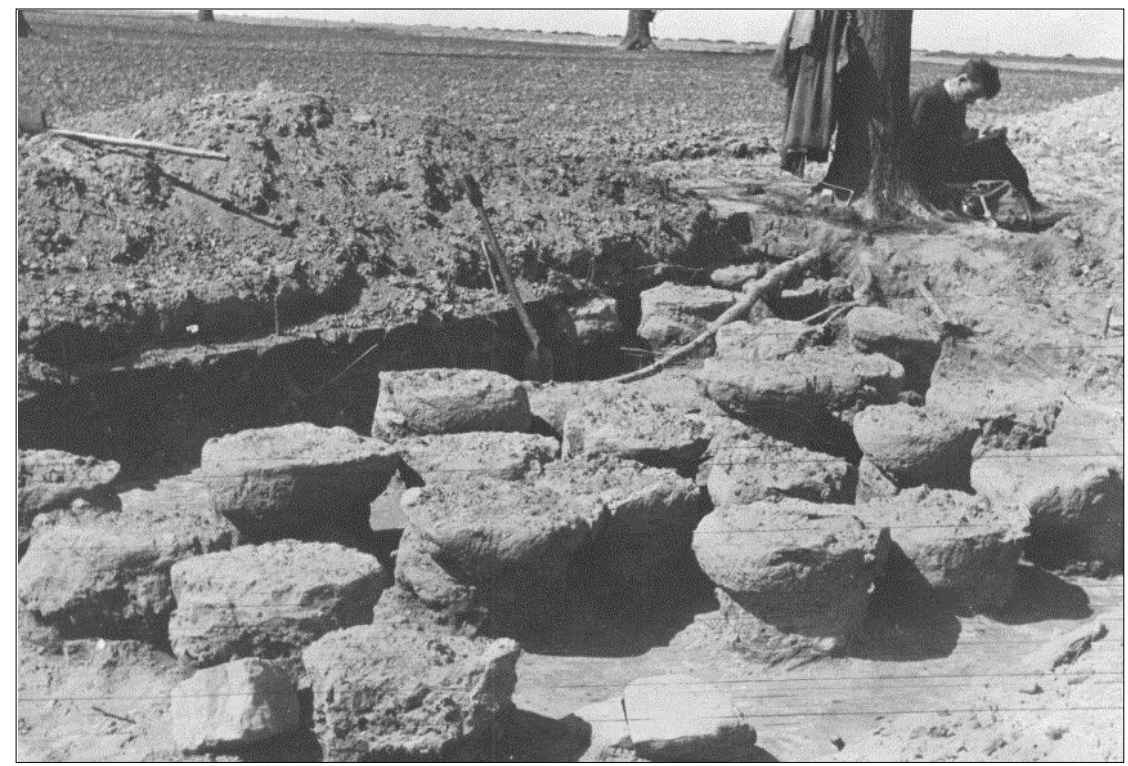

Fig. 1. Slag blocks excavated in Rudki, near Nowa Stupia - the only one that was not damaged by farming, Photo by K. Bielenin 
There were several reasons for this. Firs of all, deep ploughing would contribute to the destruction of bloomery stations in farming areas. What is more, the slag block was an excellent iron-bearing material and as a result it was used as a charge in the metallurgical process. Iron metallurgy in $18^{\text {th }}$ and $19^{\text {th }}$ century used "old slag" for the secondary melt. Such practices were also common in Poland, especially in the Świętokrzyskie Mountains [8-10]. Old slag was melted in blast furnaces in Starachowice and Ostrowiec as well as some Silesian metallurgical plants in the 1930's [11-12].

The smelting settlement in Pokrzywica shows how the stations were exploited as far as slag blocks are concerned. Among 8 investigated stations containing 466 pits only the bottom layers remained untouched (Fig. 2) [13-14]. Generally speaking, we are dealing here with an utter destruction of these stations. Fortunately, there were places where farming did not reach the pits and slag blocks were preserved. Sometimes several slag blocks at the edge of the forest or in the farmer's yard could serve as a proof of the smelting place. The dug out slag was used for many things at the farm. It was a building material or road grit.

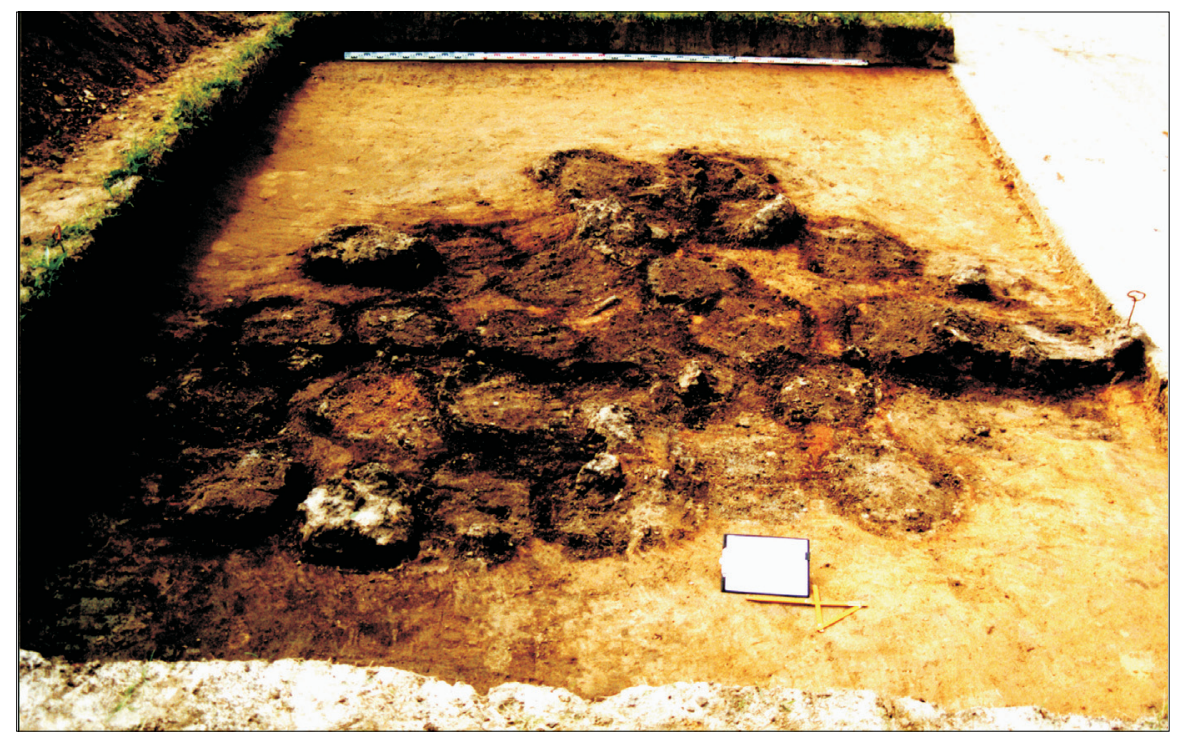

Fig. 2. Disorganized furnace cluster in Pokrzywica, station 1, near Nowa Stupia, Photo by S. Orzechowski

As far as archaeological research is concerned, the pits filled with slag were a clear piece of evidence pointing to the bloomery process (Fig. 1, 3). The shaft part was discovered extremely rarely. The shaft was build out of bricks made form clay and chaff. These elements could be burnt and hardened only up to a certain height as a result of a reaction between slag and their inner layer. After the melt had finished, the bloom had been removed and the shaft had been disassembled, some of the better preserved parts of the shaft could be used again for the construction of another furnace. The remaining part of the shaft would 
be scattered over the working area. The atmospheric conditions would contribute to its dis-appearance. Repetitive ploughing, soil erosion as well as denudation and landslides destroyed the shaft even further. Up to a certain point the pits filled with slag blocks were not subject to any damages. However, when they became an obstacle to farming they were destroyed together with the cultural layer up to the very bottom of the furnace.

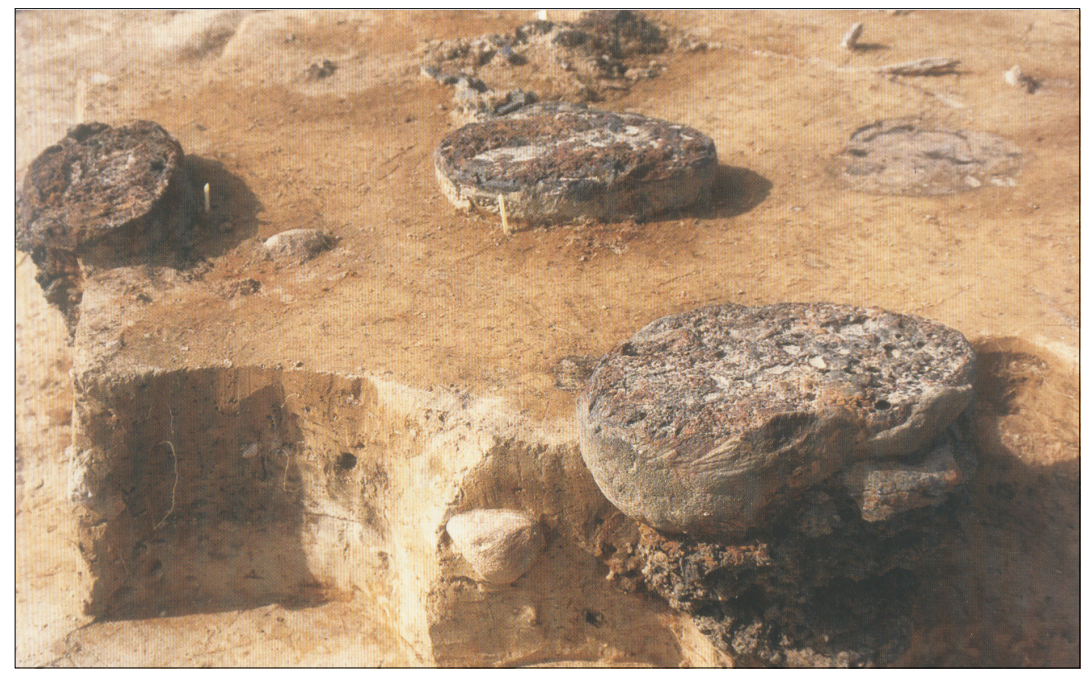

Fig. 3. Several preserved pits with undamaged surface of free solidification in Wolkenberg (Germany, Lower Lusatia) according to [31]

The archaeological research did not unequivocally point to how the air was blown into the furnace. The rare discoveries of preserved larger parts of shafts as well as shaft bricks with traces of inlets allowed archaeologists to assess the size of these inlets but they did not supply any information concerning their numbers, location and technology used. The lack of clay pipes was assumed to prove that the ancient smelter did not use bellows to blow air into the bloomery. In the Świętokrzyskie Mountains archaeological research into 100 slagpit furnace clusters led to a discovery of only several shaft parts with rounded holes having the diameter of approx. 6-8 cm [9]. At the same time the researchers in Mazovia region discovered parts of a shaft which seemed to have the form of a rectangular clay tile (approx. $11 \times 14 \mathrm{~cm}$ ). The tile had holes whose diameter was approx. $1.5 \mathrm{~cm}$ [15]. Similar holes with the diameter of $3 \mathrm{~cm}$ were found in the preserved parts of shaft from the Scharmbeck furnace in Germany [16].

The knowledge of the pit is much broader. Different sizes, depths and diameters are known $[9,17]$. The pit sometimes had a channel (a so called pit channel) which had the diameter of 8-10 cm and which connected the pit to the surface of the terrain outside the shaft wall. It is commonly found in the Świętokrzyskie Mountains, more often among disorganized furnace clusters - both the small ones (Mirgonowice) and the bigger ones (Kunów 3) [9]. The 
slag block and its structure is also known (Fig. 1,3). The upper part of the block has a solid structure. The middle part has a porous structure with wood, charcoal or even straw impressions. The bottom part consists mainly of black humus with ashes, slag which solidified while trickling down and then fell off the block as well as rare cases of pieces of unburnt charcoal [17, 24].

Despite long archaeological research into pit stations in various areas between the Vistula and the Elbe (including the Świętokrzyskie Mountains, Mazovia and Silesia) no form of iron bloom has been discovered. The lack of any traces of forges in the investigated areas seems to undermine the thesis that the ready made iron goods were produced within the boundaries of the slag-pit furnace clusters. The furnace cluster would make a semi-finished product having an agreed size, shape and weight - all of which have not been specified by researchers yet. It can be assumed that the iron bloom from the Świętokrzyskie Mountains and Poland in general was similar to this obtained in Norway. Iron blooms were round and weighed approx. from $8.5 \mathrm{~kg}$ to $17.2 \mathrm{~kg}$ [18-19].

While investigating the bloomery stations in Poland one could notice the development of the bloomery furnace. It started with a small pit with the diameter of approx. $30 \mathrm{~cm}$ (Kunów 1 type) where the slag block weighed approx. $10 \mathrm{~kg}$. Then there was a more common case of a pit having the diameter of approx. $40-50 \mathrm{~cm}$ and a slag block which weighed $100 \mathrm{~kg}$ or more. The final case consisted in large furnaces in Tarchalice (Silesia) where the pit had the diameter of $80 \mathrm{~cm}$ and the slag block weighed $300 \mathrm{~kg}$. The walls of the pit in Trchalice were reinforced with poles and the slag block itself had a characteristic bulge in the upper part in the form of a so called slag cap.

Small and middle size pits are typical of the Świętokrzyskie Mountains. Their slag blocks weighed from $10 \mathrm{~kg}$ to $100 \mathrm{~kg}$. Numerous slag stations were discovered in other parts of Europe, for example in southern Brandenburg and Lusatia, in the regions of Cottbus, Luckau, Fisterwalde and Herzberg. In 1975 scientific investigations were conducted by the Museum für Ur und Frühgeschichte Potsdam together with the Archaeological Museum in Kraków and the Institute of Material Culture at PAN (Polish Academy of Sciences) in Warsaw. This study allowed the researchers to specify two types of the bloomery furnace: a small one with a $45 \mathrm{~cm}$ diameter pit and $70 \mathrm{~kg}$ slag block and a big one with a $60 \mathrm{~cm}$ diameter pit and a slag block that weighed more than $150 \mathrm{~kg}$. The state of preserved stations was most often very bad. Seriously damaged pits were extremely common. In a 19 slag-pit furnace cluster in Zells Bahren only 5 pits had undamaged slag blocks. [20]. According to T.Voigt the bloomery furnace and slag blocks were widely known in the region of Halle, Magdeburg, Leipzig, Dresden, Cottbus and Potsdam. A station in Gera Tinz was discovered and studied in the region of Thuringia [21-22]. A big, 213 pit station with slag blocks was also discovered in Mecklenburg, in the region of Schwerin. 45 pits were found in the district of Perleberg, 100 in Ludwigslust, 58 in Hagenov and 10 in Parchim. Unfortunately, these stations were badly damaged due to farming. Nowadays there are no slag blocks there. Sometimes it was even hard to find any pieces of slag around them [23]. 20 entire slag blocks from these excavation sites are on display in the Ludwigslust Museum. 
In the area of Lower Saxony slag blocks were being dug out in the interwar period. The postwar research showed an especially big concentration of blocks in the area between the Elbe and the Weser, around the city of Bremerhafen in the district of Wesermünde and Hagen. 300 slag stations were catalogued there. The biggest discovered stations included the slag-pit furnace cluster in Hatten-Steckermoor (in the district of Oldenburg on the Isernbarg hill), which had 55 pits [24-25] as well as a station in Westerholz (in the district of Rotenburg) where 118 pits were discovered between 1966 and 1969 [26-27].

Very big slag-pit furnace clusters in Denmark (Drengsted, Snoruo, Tistrup) also provided only several undamaged slag blocks. These stations included several hundred almost entirely damaged pits [28].

In Schleswig-Holstein and in Jutland the slag stations were being damaged already in mid $18^{\text {th }}$ century due to steam ploughing. In the region of Schleswig a lot of damage was done in the interwar period when the extraction of bog iron for the ironworks in Lübeck and Ruhr Area began. At the time the slag blocks were dug out in the area of Goldebeck and Joldelund. Jöns discovered over 500 furnace pits in a station that came into researchers' focus in the early 1980's. $98 \%$ of the pits did not contain the upper parts of slag blocks [29]. Only the lower parts of the block with the remnants of slag-filled areas were preserved. In the entire Joldelund area only one pit was preserved in one piece. The slag block in it was slightly damaged. The block weighed about $170 \mathrm{~kg}$ [30].

Similar situation occurred in the area of a brown coal mine in Welzow Süd (the region of Lower Lusatia) where a big bloomery site was discovered. During rescue investigations conducted from 1994 to 1999 over 1000 bloomery pits with 30 separate stations were discovered. The pits were badly damaged due to farming. Their lower and bottom parts contained remnants of slag blocks in the porous and stalactite form. Several undamaged pits with slag blocks were preserved in Woldenberg station number 30. The surface of the blocks is visible there (Fig. 3). The preserved blocks weighed from $115 \mathrm{~kg}$ to $194 \mathrm{~kg}$ [31-32]. A similar site was discovered in Upper Lusatia - in front of a brown coal mine. The number of the bloomery furnaces there amounts to 500. The pits were seriously damaged, they did not have the upper part [33-34].

Seizing Volkswagen's initiative researchers conducted an interdisciplinary research programme into iron archaeometallurgy between 1995 and 1998. This 3 year long programme encompassed a period beginning in the ancient times up to early Middle Ages. The programme aimed at obtaining a detailed analysis of local ore resources and registering bloomery stations in the context of these resources. 176 archaeological stations connected to ancient settlements were discovered. In these sites there were 26 slag-pit furnace clusters grouping from 4 to over 30 pits. The pits had the diameter of $40 \mathrm{~cm}$. They were dug up in sandy soil and were badly damaged due to farming. It turned out impossible to find a single slag block that would have an undamaged upper surface. In Altiebel researchers found a pit filled with straw which was charred under the slag. Regions with a bigger concentration of bloomery stations (Luppa and Lomskie) were discovered. Layers with early Slavic ceramics and layers of slag from broken slag blocks were found [35]. 
Recent years proved that the bloomery furnace was also present in eastern Ukraine. Apart from the already known site in Nowoklinow in Carpathian Ukraine [36], researchers discovered a new site in Zhytomyr district, another one in Uman region and one further in the east - in Podwyskoje [37]. At the moment it is still difficult to assess how well preserved these sites are.

The above presented analysis of archaeological data proves how insignificant and onesided the data may seem. The slag block and the pit remain the most fundamental witnesses of the bloomery process. The size of the block shows clearly how big the furnace was. The iron slag that filled the pit comes from the entire ore charge used for this smelting process. The analysis of iron obtained in one pit shows how much ore, raw material and charcoal was used as well as how much iron was produced at the workshop or at the entire bloomery site. So far slag blocks were not in the focus of research. Only a few works provide some data concerning their chemical and structural composition. The average amount of metallic iron was also assessed. In the block from Kunów it is from 0.03 to $0.81 \%$. The particles of metallic iron measured form 0.03 do $0.91 \mathrm{~mm}$ [38]. The amount of metallic iron in the slag block from Pokrzywica was $0.68 \%$ [39]. It corresponds to data published by Neumann, who studied slag from Roman times that was found in Western Germany. He gives the following figures: 0.23 to 0.63 [40].

Such a small interest in slag blocks can be attributed to the common presence of slag in these places. Undamaged slag blocks are found extremely rarely in Central and Northern Europe. However, in Poland (in the Świętokrzyskie Mountains and Mazovia) some slag blocks were collected during the excavation works. Muzeum Starożytnego Hutnictwa Świętokrzyskiego im M. Radwana [The Museum of Ancient Metallurgy in Świętokrzyskie Region named after M.Radwan] has a collection of 31 slag blocks from different furnaces. Similarly, Muzeum Starożytnego Hutnictwa Mazowieckiego im. Stefana Woydy [The Museum of Ancient Metallurgy in Mazovia named after Stefan Woyda] has collected a considerable amount of slag blocks.

Each block that is in one piece and that filled the pit of the furnace constitutes evidence what the furnace looked like and how it worked. The preserved blocks with an undamaged upper surface are a precious material not only for display but also for research.

\section{THE STATE OF EXPERIMENTAL RESEARCH INTO THE BLOOMERY SHAFT FURNACE WITH A PIT}

A close scientific cooperation between archaeologists and metallurgists resulted in conducting experimental melts at the initial stage of research into ancient metallurgy in the Świętokrzyskie Mountains. Being an engineer professor Radwan wanted to know what the upper part of the furnace looked like as it was the place where the reduction process took place. He also tried to discover where the reduced iron gathered as it was found neither under the slag nor at the bottom of the pit.

The experimental melts were supposed to help not only to recreate the bloomery furnace. The researchers were in the dark as far as the bloomery process was concerned. The 
charge used, the type of ore, fuel, their amounts and what is equally important the obtained metal and its characteristics remained unknown. The research plans outlined a series of experiments in which different types of ore, charcoal, natural and artificial draft were to be used. The experimental research was supported by a continuous analysis of the excavated material at the slag stations.

After several experiments conducted in a lab, in 1957 professor Radwan conducted the first experimental melt in a truck factory in Starachowice (Fabryka Samochodów Ciężarowych w Starachowicach). In 1960 the research was taken up at the AGH University of Science and Technology in Kraków. Dr Radomir Pleiner, a Czech researcher, took part in these experiments thanks to the cooperation between Zespół Historii Polskiej Techniki Hutniczej i Odlewniczej [the team investigating the history of Polish metallurgical and casting technology] at PAN [Polish Academy of Sciences], the Archaeological Museum in Kraków, AGH and the Institute of Archaeology at the university in Prague. Initial experiments involved the same pit without an upper structure. Further trials involved a pit with an upper structure measuring $20 \mathrm{~cm}$ in height. Using an artificial blow the researchers obtained an iron-slag conglomerate - similar to that from a Czech furnace from Lodenice [41-42].

From 1962 to 1967 experiments were conducted next to a newly built Museum in Nowa Słupia. The experiments were extended to charring wood in piles and ore calcination in recreated kilns. The shaft was extended to $50 \mathrm{~cm}$ and the walls were formed a cone. The melt was carried both with an artificial draft produced by means of two hand bellows or with a natural draft. Dr R. Pleiner took part in the research in Nowa Słupia. Hematite ore from the mine in Rudki was used for the experiment. The ore was subject to calcination in a kiln. Mixed charcoal form beech and pine was also used. During 9 hours in the shaft $91 \mathrm{~kg}$ of ore was transformed into a $70 \mathrm{~kg}$ slag block. In 1963 researchers used a highly phosphorus ore in order to obtain clear data concerning the transition of phosphorus into metal and slag. In 1964 the experiments were continued in Brzeźna in Czechoslovakia together with the Institute of Archaeology of the Czech Academy of Sciences. The experiments were conducted in two different furnaces - one of the Scharmbech type (with a pit), the other of the Zelechowice type (a built-in one) [40,60]. During 7 experimental melts between 1965 and 1967 the researchers tested the type of draft and ore. When natural draft was used, the shaft was extended up to $130 \mathrm{~cm}$. The charge consisted of highly phosphorus ore or a potential resource that was exploited in the ancient times in Rudki.

Professor Radwan conducted 31 experimental melts between 1957 and 1967 [44-53]. Their results led the researchers to believe that the obtained iron in the form of an iron slag sponge was different form the ancient smelter's product (Fig. 4). Professor Radwan was aware that recreating the smelting process was a complex issue, more complex than some had thought. In 1957 he wrote, "Today we can say that the experiments proved how skilful ancients smelters were. They were able to obtain results in an extremely complex smelting process, a process in which reduction, oxidation as well as carburization and decarburization occurred. It was easy to burn the reduced bloom [52]. It was the first time when a Polish metallurgist emphasized high skills of ancient smelters. He noticed that he lacked their practical knowledge which allowed them to separate liquid slag from the molecules of iron that was being reduced. Slag blocks seem to prove the ancient smelter's ability to do so as there is a negligible amount of microscopic iron grains in the block [18]. Researchers from other countries (Czechoslovakia, Germany, Denmark, France) obtained similar results. 


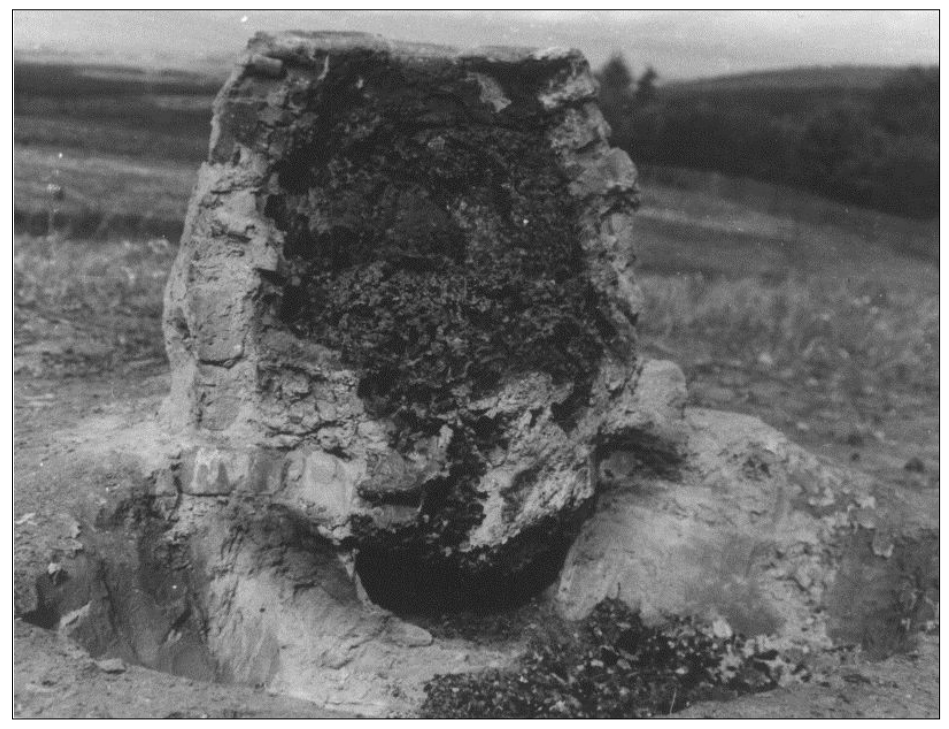

Fig. 4. A cross section of a bloomery furnace after an experimental melt in Nowa Stupia in 1962, Photo by K. Bielenin

Professor Wacław Różański was the successor of professor Radwan in terms of the reconstruction of the ancient smelting process. Work [54] presents a wide spectrum of his experiments conducted within the scientific research group called "Officina Ferraria". Main results of this part of research consist in standardization of the furnace height (from 80 to $120 \mathrm{~cm}$ ) and using a mixture of coal from deciduous and coniferous trees as fuel. The experiments also led to a presentation of an arguable view that there were two stages of the smelting process: "do the blocks left in the fields come directly from the smelting process? Or are they the remnants of the second stage of the process which consisted in separating iron sponge from slag?" [55]. The results of the experiments supported a thesis that the slag block contained an amount of spongiform iron. This amount had to be separated from the block. The results showed that the slag blocks found in the fields in Świętokrzyskie region were devoid of iron and that is why they were left by the smelters in the slag-pit furnace clusters.

As far as foreign researchers are concerned, one should pay attention to Rosemarie Leinewber (Landesamt in Halle) and Bernd Lychatz (the TU Bergakademie Freiberg). These authors conducted a series of 25 experimental melts in a shaft furnace with a pit. These experiments were conducted from 1990 to 1998. They cooperated with other researchers from the Netherlands, Denmark and Norway - countries where bloomery furnaces of the type in focus were found [56-57].

One should not overlook the experiments conducted by Olfert Woss [58], H. Barbe, R. Thomson [59] (Denmark), R. Pleiner (the Czech Republic) [60,67], V. Pawliska (Germany) [61] and Phillipe Andrieux (France)[62]. Nikulka assesses the number of conducted experiments as 230 . He presents reports for 165 of those experiments. The reports differ when it comes to the amount of detail he presents. He assesses the total amount of experiments in this field to be from 300 to 400 [63]. 
During the experiments conducted both in Poland and abroad researchers obtained an iron-slag conglomerate mixed with charcoal. The conglomerate gathered below the air inlets. It proved impossible during those tests to get entire slag in the pit. These results presented researchers with a serious problem. Polish and European researchers accepted the fact that the bloom of the ancient smelter had such a form. Therefore, the literature contained views that the bloom was contaminated and had to be purified by further treatment such as heating and forging.

Such a view was presented from the very beginning of the experiments and was repeated until 1992 [9]. The dens and pits found around furnace clusters were considered to serve as places for heating and purifying iron from slag $[9,14,15]$.

The problem of contaminated bloom is known in some of the ancient bloomery furnaces where smelting was done repetitively. One can mention here the furnace built in the walls of a workshop in Igołomia [64], furnaces with a pit in front of them in Burgenland [65], Siegerland, Engsbach [66], early medieval furnaces from Żelechowice [67], the furnace of Imola type in Hungary [68]. Similar methods were observed in contemporary furnaces in Africa [69]. Fractions of metallic iron coagulate into a bloom and place themselves among slag below the reduction zone. After the process had finished the ancient smelter was forced to remove the post smelt filling from the furnace chamber, to select the main lump of metal as well as its smaller parts. The bloom from the melt had a form of spongiform iron, i.e. iron mixed with slag. Obtaining pure lump of iron from the bloom required a separate process which consisted in heating it up, forging in order to get a semifinished product. These operations were carried out in settlements where furnaces with some remnants of walls, air inlets or pits in the ground.

There are some views shared by researchers and archaeologists which provide us with an approximate picture of the ancient smelting technology. What is more, these views are not in contradiction to archaeological data [54]. One of these views concerns the general structure of the furnace, its shape, material used to build the shaft, the way the pit was made as well as the charge used. The charge consisted in a mixture of coal and ore without any fluxes.

The experimental research aimed at recreating and getting to know the reduction techniques and the way iron was obtained in ancient Poland. Researchers wanted to learn more about the so called direct reduction thanks to which ancient smelters were able to obtain a lump of malleable iron. What seems unusual is how reduced iron was separated from slag in the smelting process. It still remains a mystery how an ancient smelter was able to do so. This achievement can be seen as the first technological revolution at the very beginning of metallurgical technology [69].

The weakness of the result consisted in a side-product totally different from the bloomery slag - a slag block with a characteristic surface. Iron bloom was not obtained separately, either. This fundamental difference makes one change one's perspective on the bloomery process. This in fact is the subject of this work.

\section{ARCHAEOLOGICAL CONCEPT OF “THE SURFACE OF FREE SOLIDIFICATION" ON THE SLAG BLOCK}

Slag blocks as well as single pieces of slag from ancient bloomery processes were characterized and classified in various scientific works. Their weight and dimensions were 
given. Their shapes and characteristic areas in their cross sections were described (uniformly melted in the upper part, porous, with coal impressions in its middle part, stalactite in the lower part). Single pieces of slag were classified as porous, stalactite or foamy $[17,24]$. This description was not expanded, especially when it comes to the bloomery process.

The elements of the surface structure of slag blocks were mentioned by the author for the first time in an article "Iron slag as an archaeological source in relation between iron slag and the type of the bloomery furnace and the other way round” (,Żużel żelazny jako źródło archeologiczne w relacji żużel żelazny typ pieca dymarskiego i odwrotnie") [70]. In 1985 researchers in Wissenschaftliche Arbeiten aus Burgenland noticed that the structure of the slag block surface contains answers to numerous problems connected to the bloomery process [71]. It seems difficult to explain today why these comments were not taken into account in the $2^{\text {nd }}$ edition of "Starożytnego Hutnictwa Świętokrzyskiego" ["Ancient Metallurgy in Świetokrzyskie Region"] in 1992. The problem was within author's interest which can be proved by an article in Archeologia Austriaca [72], where the surface of free solidification was documented with photos of slag blocks from the Świętokrzyskie Mountains. Author's interest in the issue was also expressed in a review of H.Jöns's book Preähistorische Zeitschrift [30]. A work within a monograph "Hutnictwo Świętokrzyskie i inne centra i ośrodki starożytnej metalurgii żelaza na Ziemiach Polskich" ["Metallurgy in Świętokrzyskie region and other centres of ancient iron metallurgy In Poland" ] is an example of an intensive study of the upper part of the slag block and the surface of free solidification. All the conclusions drawn from this analysis were presented in the form of 12 theses [69]. The latest work on this subject focuses on the slag block from Boleszyn. The surface of the block is extremely diverse when it comes to its structure. It has elements that support the results of the previously conducted analysis. [73].

The structural elements of the block's upper surface, which are defined as the surface of free solidification, were distinguished by long observation of the slag blocks. Figure 5 presents characteristic examples of the surface of slag blocks. These blocks come from different regions of Poland. The elements can be characterized as follows:

- the surface of the blocks is usually flat, smooth in certain parts, glossy and dark grey

- gas cavities are visible on the surface of the block, cavities are of different sizes

- the edge of the block is clear, it is characteristic of casting shrinkage

- upper surface of the block is sometimes wrinkled, it means that the liquid slag moved intensively before solidification

- some amount of loam and even bigger parts of the shaft are melted in the block

- there are certain red areas on the surface which are connected to the melted ore, brown fractions melted in the block are also encountered

It needs to be added that not all mentioned elements of the structure of free solidification have to be visible on the surface of one block. The most important and most common elements include the traces of gas cavities and melted fractions. The way the block looked like is also quite common. Slag filled the pit up to its upper edge in its entire circumference. Looking at the block from the outside one can distinguish two spheres. The lower one is porous and has stalactite fractions and loose charcoal. It takes up to $1 / 3$ of the block's 
height. The upper part is solid and it fills the pit up its upper edge. These two spheres were observed irrespectively of the size of the pit. They were present in smaller furnaces Kunów 1, middle size furnaces and big pits in Tarchalice. The structural analysis of the elements of slag blocks provides important conclusions concerning the final phase of the bloomery process. During this phase iron bloom was formed and slag flowed down into the pit. The bloom was optimally deslagged and the structure of the bloomery furnace enabled these processes to take place.

a)

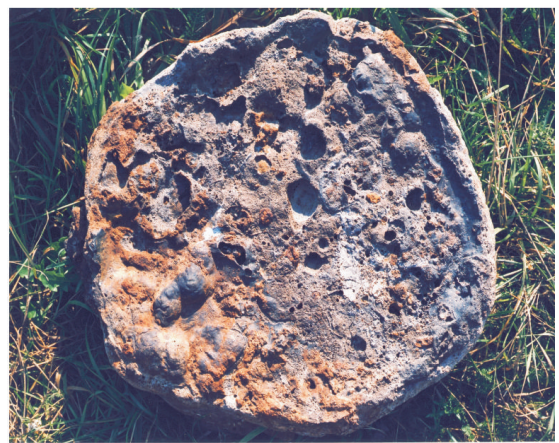

b)

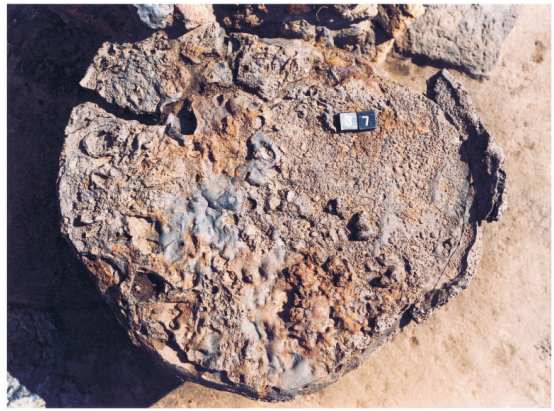

c)

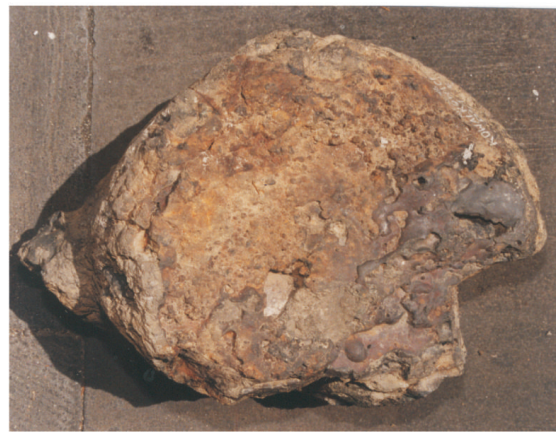

d)

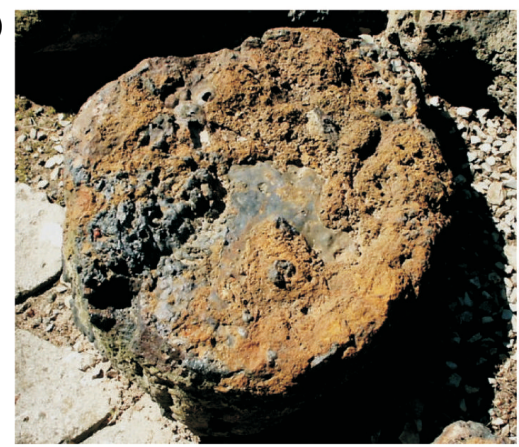

e)

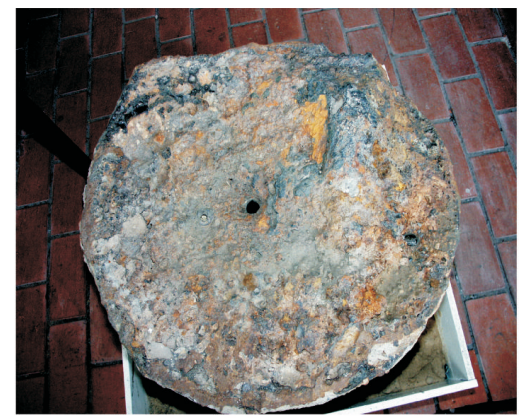

f)

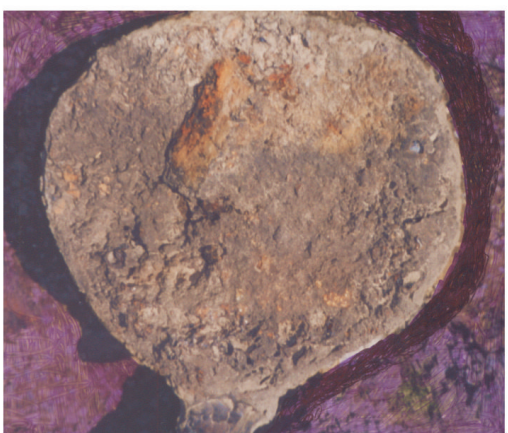

Fig. 5. The surface of slag blocks from archaeological excavation sites in the centre of ancient iron metallurgy in Świętokrzyskie and Mazovia regions a) Młochów; b) Brwinów I; c) Kowalkowice; d) Garbacz-Skała 5; e) Kałków; f) Garbacz-Skała 57 
As a consequence, one may claim that

1. Ore reduction, iron bloom formation as well as deslagging of the barren rock and liquefying of slag took place in the shaft.

2. The part of the shaft that was above the pit was filled with inflammable loose material and it allowed the liquid slag to gather temporarily and keep the temperature. Similar filling of the pit could keep slag in the shaft until the amount of it was so big that the filling gave way to it. It seems admissible that there was a grate separating the shaft and the empty pit. Such a grate would have to be burnt entirely in the final phase of the process as no traces of it were found during archaeological excavations.

3. When slag got to the pit it was highly fluid. Slag filled the pit entirely.

4. Very small amount of scattered microscopic grains of metallic iron in the slag block shows that only pure slag filled the pit.

5. Iron bloom was above the surface of free solidification. It hang onto the inner shaft wall.

6. Flat surface of free solidification shows that when the melt was over, the ancient smelter did not have any trouble to get the iron bloom out. He did not have to forge it out of the slag block.

7. The ancient smelter knew exactly when he had to inject the ore charge for the last time. He had to make sure that the level of flowing slag did not rise above the edge of the pit, a fact which could tamper with total deslagging of the metallic zone of the iron bloom. Slag flow seems to be a holistic phenomenon. It took place only once and finished the smelting process.

8. Iron bloom was probably removed after reduction had taken place and liquid slag had flown down. The hot shaft was disassembled. This could explain why some slag blocks contained traces of loam or even parts of the shaft.

9. The deslagged iron bloom did not require, as was previously thought, any laborious treatment such as purification by means of heating and forging. Iron blooms, similarly to those from multi use furnaces, were not so much forged but shaped in order to compress the inner structure of iron, divide it and obtain desirable size and form.

The above presented solutions are based on how numerous slag blocks looked like. The characteristic surface of free solidification on slag blocks can be seen as typical of ancient bloomery furnaces of the pit type common not only in Central and Northern Europe.

\section{METALLURGICAL VERIFICATION CONCERNING THE ARCHAEOLOGICAL CONCEPT OF THE SURFACE OF FREE SOLIDIFICATION}

The above presented theses apply to the final product, i.e. the iron bloom and waste materials of the process, i.e. the slag block. Taking into consideration the importance of this concept it seemed necessary to provide an analytical verification of the ancient smelting process. The research was based on the only direct material evidence, i.e. the slag block. Such an approach made it impossible to verify theses concerning the iron bloom as it was not available. Nor were the traces of removing it from the furnace. The particles of iron and iron goods excavated near the furnace clusters can indirectly support our theses concerning the iron bloom. 
It was assumed that highly fluid slag flowed down into the pit. The flow occurred in the final stage of the process, after reduction had finished. The verification of this thesis was possible thanks to the results of structural and analytical studies of the slag block cross sections. The primary structure of the block that was an effect of solidification as well as the phase segregation of elements on its cross section can explain the following:

- how the block solidified,

- what the initial solidification temperature was,

- what the heat transfer conditions were

- the continuity of the process.

If one accepts the model specified in the above theses, one can expect a clear correspondence between solidification when it comes to the slag block and the ingot cast into a cold mould. The section of the block should contain the following zones (starting from the walls of the pit): the zone of ice crystals, the zone of dendrite crystals and the zone of equiaxed crystals. The components of low melting phases should pass before the solidification front. This leads to a segregation of elements around the axis of the cross section as well as to a dendrite segregation. The continuity of crystal zones and the segregation of elements on the surface of the block points to a solidification of a large amount of liquid phase and as a result it points to the flow of slag into the pit.

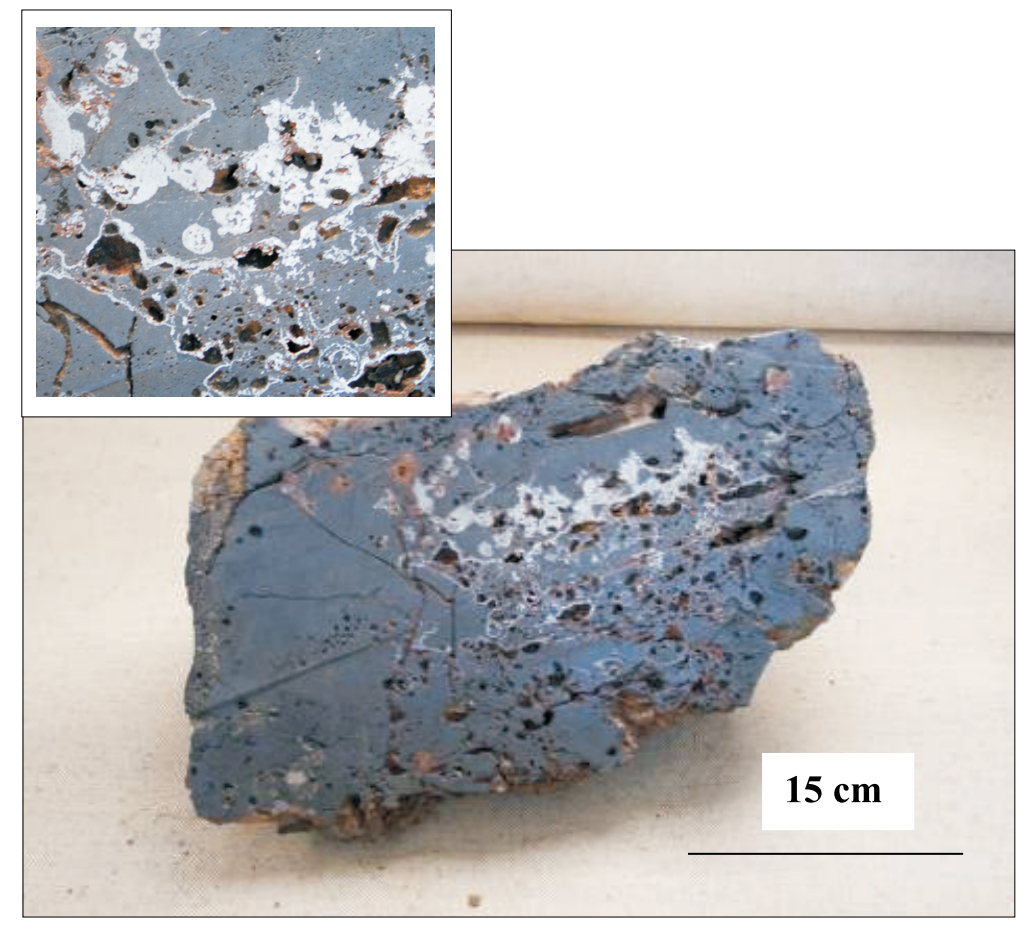

Fig. 6. The surface of the cross section of a slag block from Kowalkowice. Magnified details of macrostructure 
a)

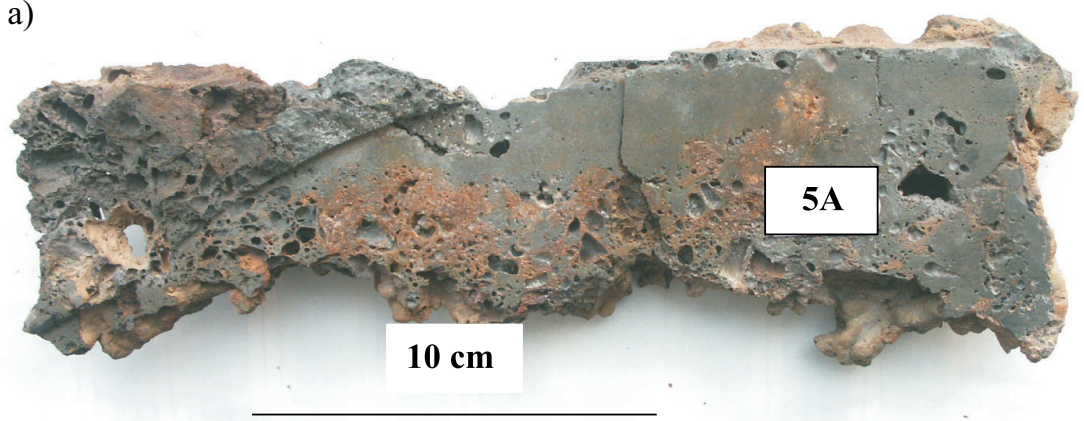

b)

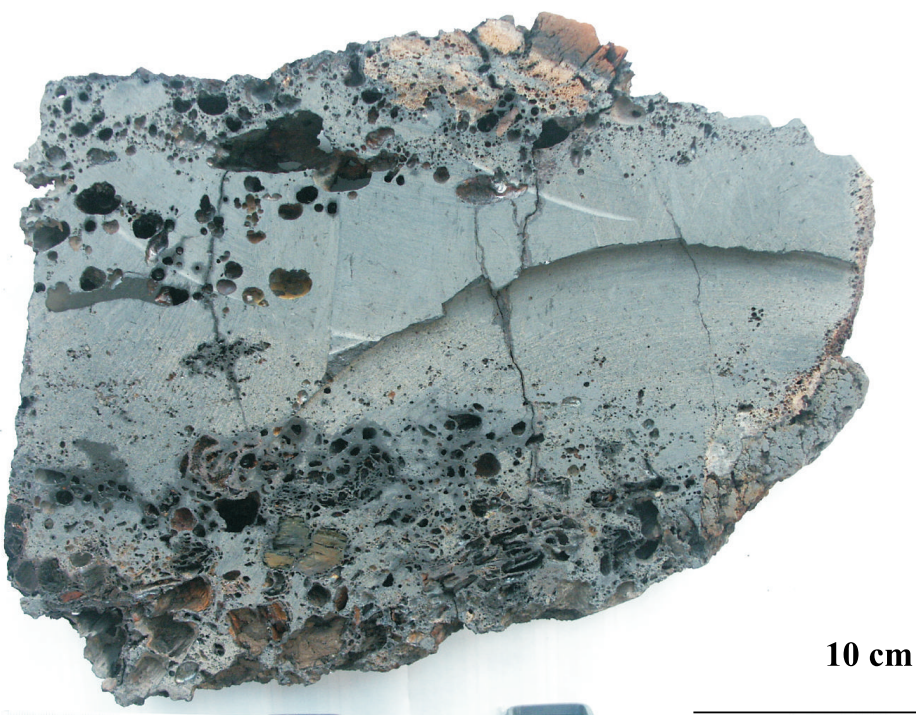

Fig. 7. The surface of the cross section of a block from Garbacz-Skata (No. 59) (a) and Garbacz - Skata (No. 57) (b)

Initial research into slag block cross sections from Kowalkowice (Fig. 6) and from Garbacz-Skała (Fig. 7) was published in Materiałach Archeologicznych [74] and in Hutnik. Wiadomości Hutnicze [75]. Further work confirmed initial results. Table 1 presents average chemical composition of the slag blocks in focus.

Table 1. Chemical composition of the slag in focus

\begin{tabular}{||l|c|c|c|c|c|c||}
\hline \multirow{2}{*}{\multicolumn{1}{c|}{ Slag station }} & \multicolumn{7}{c||}{ Oxide chemical composition [\%] } \\
\cline { 2 - 7 } & $\mathrm{FeO}$ & $\mathrm{MgO}$ & $\mathrm{SiO}_{2}$ & $\mathrm{Al}_{2} \mathrm{O}_{3}$ & $\mathrm{CaO}$ & $\mathrm{K}_{2} \mathrm{O}$ \\
\hline Kowalkowice & 45.34 & - & 43.77 & 6.60 & 1.50 & 1.79 \\
\hline Garbacz-Skała (No. 59) & 36.39 & 0.22 & 50.72 & 8.45 & 1.25 & 2.97 \\
\hline Garbacz-Skała (No. 57) & 57.32 & 0.31 & 29.34 & 8.81 & 0.86 & 3.36 \\
\hline
\end{tabular}


a)

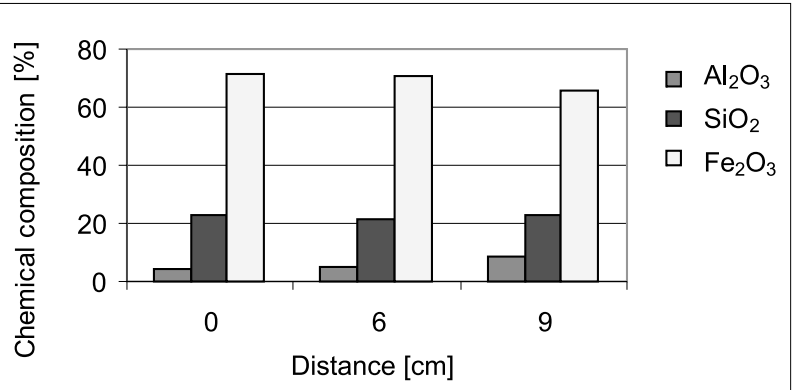

b)

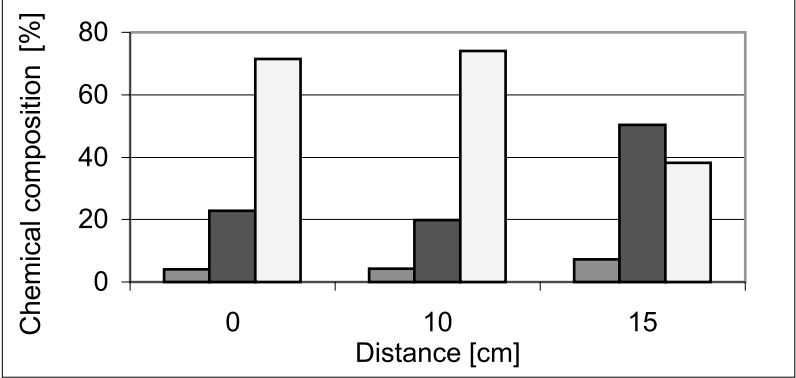

c)

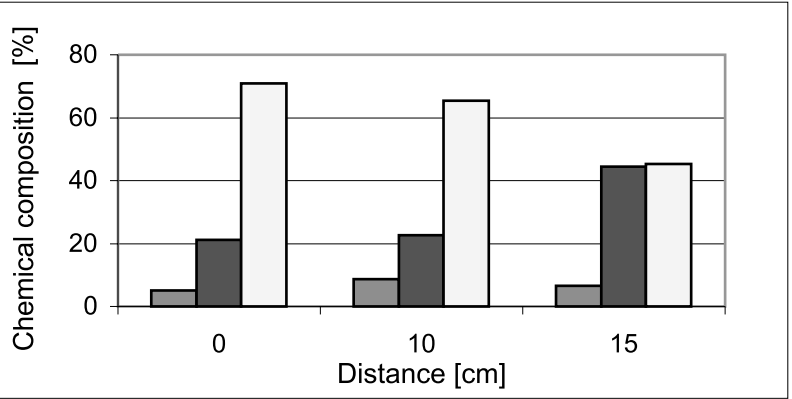

Fig. 8. The chemical composition of samples taken from a block in Kowalkowice. a) in a vertical axis of the block; b) in a horizontal axis at the depth of $4.5 \mathrm{~cm}$ from the surface; c) in a horizontal axis at the depth of $9 \mathrm{~cm}$ from the surface

Figure 8 presents the share of $\mathrm{Fe}_{2} \mathrm{O}_{3}, \mathrm{SiO}_{2}$ and $\mathrm{Al}_{2} \mathrm{O}_{3}$ in the cross section of the block from Kowalkowice. When considering the vertical axis of the cross section from the surface of the block towards its bottom, one may notice that the share of $\mathrm{Fe}_{2} \mathrm{O}_{3}$ decreases slightly while the share of $\mathrm{SiO}_{2}$ increases (a). Stronger segregation of these phases is visible along the radius of the cross section $(b, c)$ and what is more, it is visible on different levels of analysis. Slag blocks contain more $\mathrm{SiO}_{2}$ and less $\mathrm{Fe}_{2} \mathrm{O}_{3}$ near the walls of the pit. Chemical segregation in the cross section of the block leads to structural changes. Figure 9-10 show microstructures of slag block samples from Kowalkowice. Samples were taken from the surface of the side wall of the block and then from its interior finishing at the depth of $4 \mathrm{~cm}$ 
under the surface of the block. What could be observed was a systematic change from fayalite structure (light grey) through mullite structure (dark grey), silica (glossy areas in fayalite) to structures containing vistite (bright dendrites), mullite and hercenite (grey). The structure of the samples taken from the vertical axis of the cross section of the block did not show such a strong segregation as the samples taken along its radius. What is visible is a diversity in the share and the morphology of vistite and in the number of empty places gas cavities. These cavities prevail near the surface of the block. Vistite has a microcrystalline form near the surface of the block and the form of macrocrystalline dendrites inside the block. The deeper one goes the bigger share of vistite. The slag block from Garbacz-Skała (Fig. 11) has an analogous structure. Near the wall of the block at the depth of $4 \mathrm{~cm}$ one can notice eutectic nests of $\mathrm{FeO}-\mathrm{Fe}_{2} \mathrm{SiO}_{4}$ and dark grey mullite. If one gets closer to the axis, one will find not only eutectic nests but also $\mathrm{FeO}$ dendrites and hercenite. A big share of vistite characterizes the sample taken from the centre of the section.
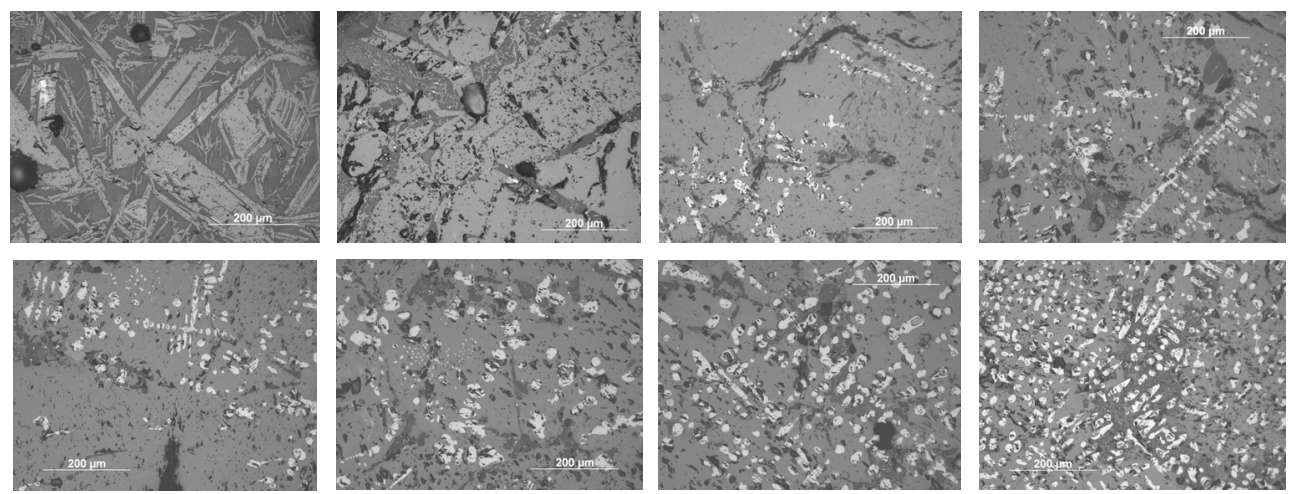

Fig. 9. Microstructure in a cross section of a slag block from Kowalkowice at the depth of $4 \mathrm{~cm}$ from the surface. Another view from the walls of the block towards its centre
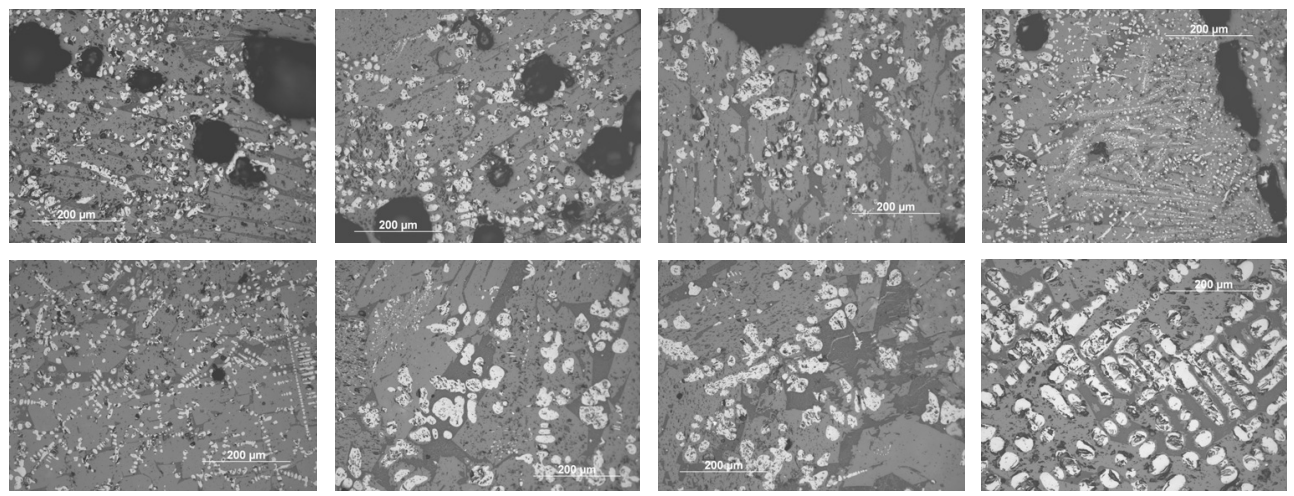

Fig. 10. Microstructure in a cross section of a slag block from Kowalkowice, a cross section along a vertical axis. Different views from the surface of the block towards its centre 
a)

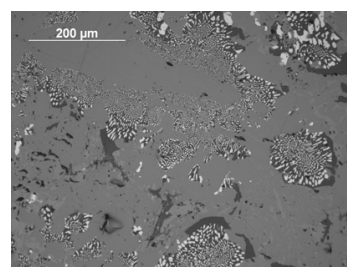

d)

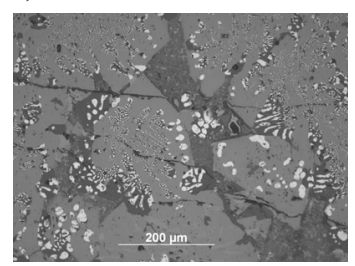

b)

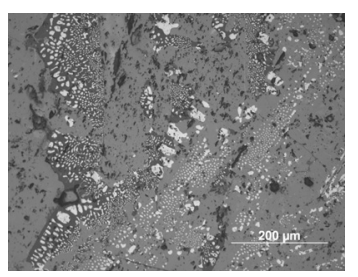

e)

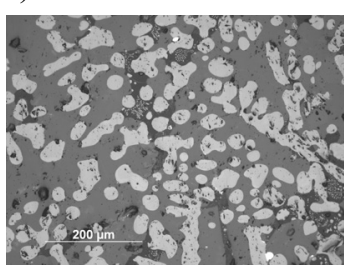

c)

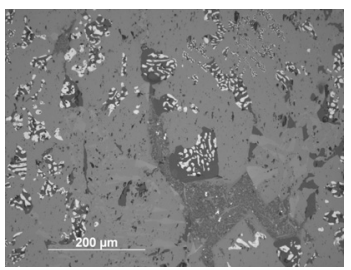

Fig. 11. Microstructure in a cross section of a slag block from Garbacz-Skała 57, from samples taken along the radius of the cross section in a distance of a) $4 \mathrm{~cm}$; b) $12 \mathrm{~cm}$ and c) $24 \mathrm{~cm}$ from the centre and along the vertical axis at the depth of d) $4 \mathrm{~cm}$ and e) $16 \mathrm{~cm}$

The results of structural observations confirmed the phase segregation in the cross section of the block and the continuity of the primary structure. It proves that the solidification of the block proceeded continuously in its entire volume from side walls and the bottom of the pit towards its centre. The final proof supporting the thesis was provided by an X-ray diffractometric analysis. High melting phases segregate near the side of the block while the low melting phases do that in its centre. There was no evidence suggesting that slag gradually flowed into the pit and that solidification was gradual. Flash furnace slag in the pit channel solidified simultaneously with the block and had the same structural continuity. The cross section showed numerous gas cavities and remnants of charcoal, ore and loam. Slag reacted with loess next to the walls of the pit. The result of this reaction was high aluminium alloy from the $\mathrm{FeO}-\mathrm{Al}_{2} \mathrm{O}_{3}-\mathrm{SiO}_{2}$ system.

Crystallized grains in the centre of the slag block from Kałków (Fig. 12) supported even further the solidification of large amounts of slag in the pit. Such big grains having a surface of free growth could solidify only when cooled. This was assured by a large amount of slag that flowed down into the pit. Another proof is supplied by the microstructure of the block cross section under a brick that fell into the pit when the shaft was disassembled (Fig. 13). Slag was so liquid that the brick was flowing under the surface of the block. The observed crystal zones (ice crystals and stubby crystals) indicate high temperature of the liquid slag in the pit.

These results support the theses concerning the way the slag block was formed in the pit of the bloomery furnace. Slag solidified in its entire volume in a way typical of solidification of cold mould casting. This led to a segregation of phases. The metallic phase of the block constitutes yet another piece of evidence supporting the above mentioned way of slag block solidification. Iron gathered in the central part of the block. It formed a capsule around gas cavities and pieces of charcoal or it formed small grains. Larger grains were not iron lumps. They were sections of capsules surrounding the gas cavities that were tangent to 
their surface (as deeper grinding showed). Their structure consisted of iron grain agglomerates. Taking into consideration iron morphology and the lack of carburization this phase may be regarded as a result of secondary reduction. What was reduced was iron from fayalite or from the vistite $\mathrm{FeO}$ remaining in the slag structure. Carbon monoxide $\mathrm{CO}$ and charcoal acted as reducers. Carbon monoxide was produced while pieces of charcoal burnt in the pit. CO could penetrate liquid slag and together with flowing pieces of charcoal could act as a reducer for iron phases in slag. Iron can be found in the place where slag remained liquid the longest. This fact seems to support our thesis.

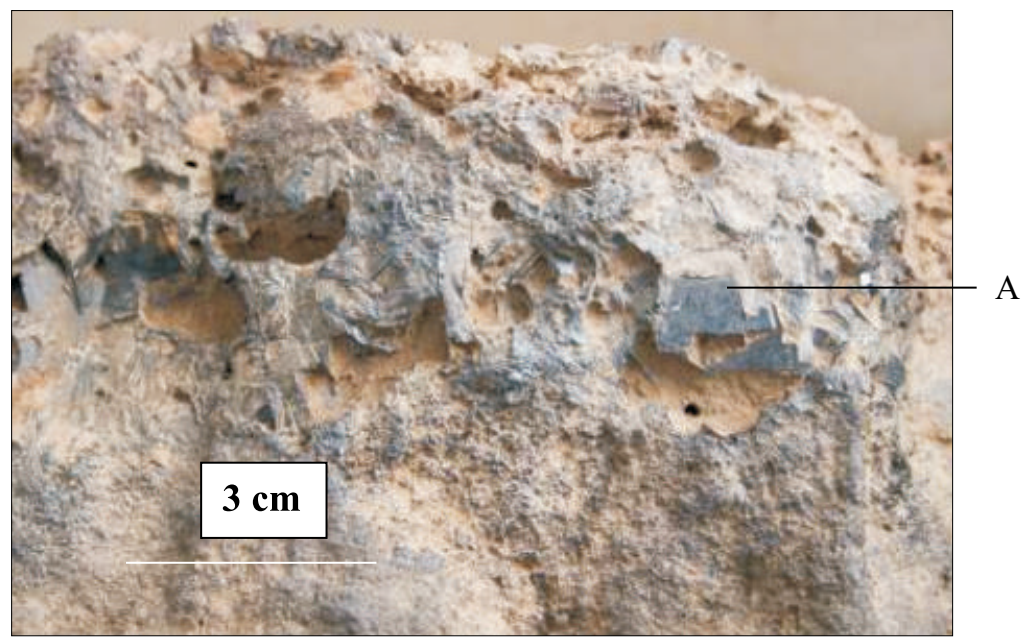

Fig.12. The surface of the fracture of a slag block from Katków. Large grains of fayalite in the centre of the block. A-Fayalite monocristal-growth plane

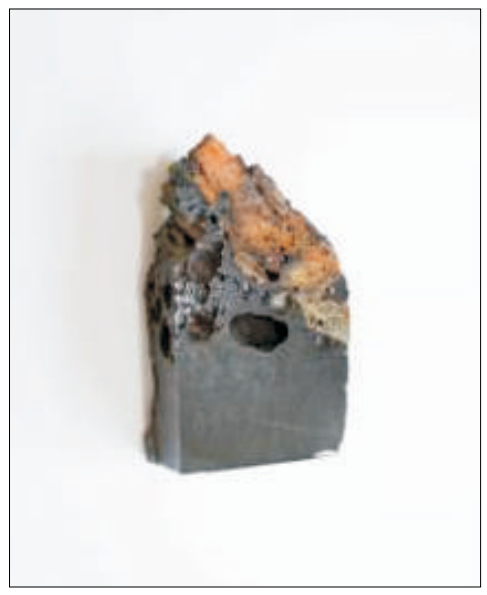

Fig. 13. The crystal structure of the section of a slag block from Garbacz-Skata (No. 57) under a brick that fell into liquid slag 
The issue of iron precipitates visible in the cross section of the slag block was explained in another work [75]. Figure 14 presents the results of a computer simulation of the phase composition of different types of slag with specified chemical composition (slag blocks in focus of research) at the temperature of $1250^{\circ} \mathrm{C}$. In the investigated systems the share of metallic phases in the presence of the reducer may amount to maximum $38 \%$ of the weight. If one assumes a $10 \%$ share of the reducer, one may expect the largest precipitates for the slag from Kowalkowice and the smallest for the slag from Garbacz-Skała 57. The actual cross sections of these blocks support this statement (See Fig. 6, 7). In simulated conditions the amount of liquid phase could be up to $40 \%$ of the weight (Fig. 15). Maximal liquidity of slag in focus could be reached at the temperature of $1160^{\circ} \mathrm{C}$.

a)

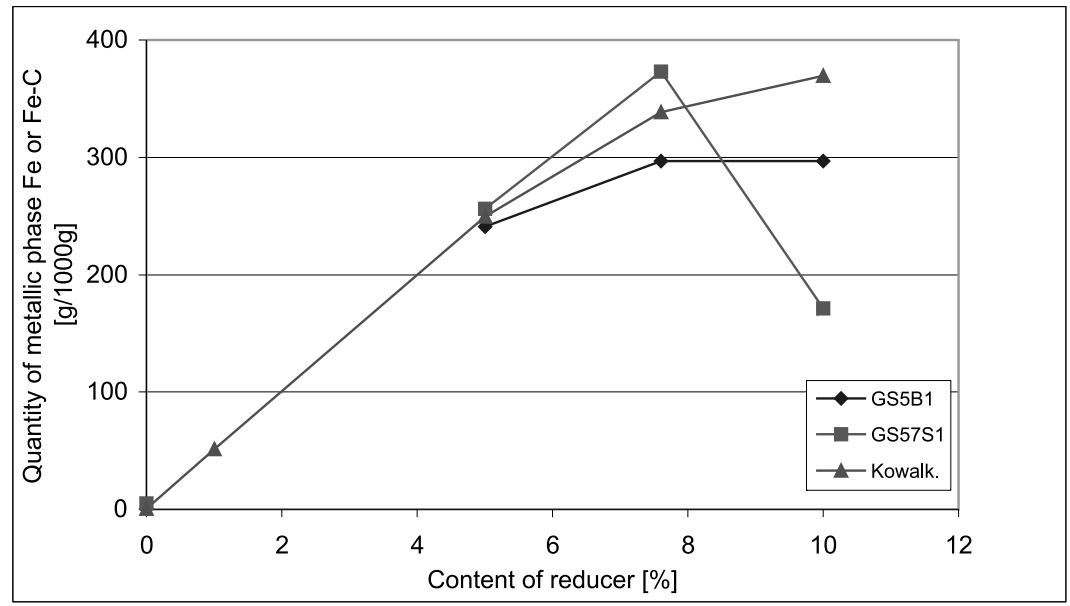

b)

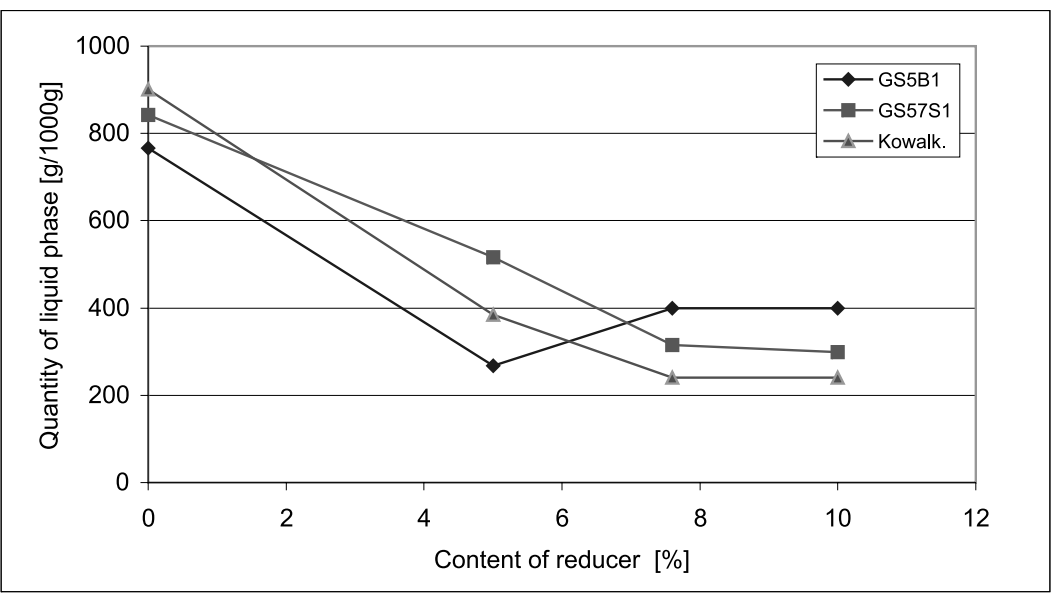

Fig. 14. Simulated influence of the reducer share on the amount of metallic phase (a) and the amount of liquid phase (b) at the temperature of $1250^{\circ} \mathrm{C}$ for the slag in focus 


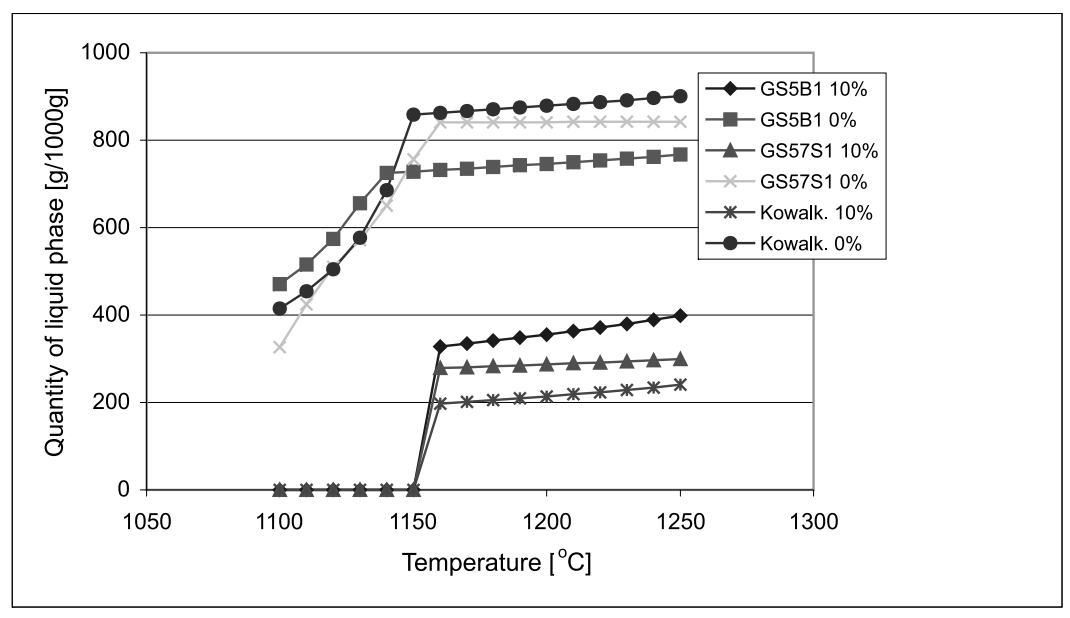

Fig. 15. Simulated change in the share of liquid phase with temperature for $0 \%$ and $10 \%$ content of reducer in the investigated slag

Computer simulations and the results of experiments provided theoretical grounds and confirmed in practice that there is a possibility of obtaining iron precipitates from slag at the temperature of $1100-1250^{\circ} \mathrm{C}$ if it is in contact with charcoal. Such conditions could be present in the pit of the bloomery furnace after slag tapping. An increased role of the reducer entailed a porous character of the samples. This fact is related to the gaseous phase that came into being during slag reduction by charcoal. As simulations showed the amount of gaseous phases with a $7.6 \%$ and a $10 \%$ share of the reducer was 1.5 times higher than in the case of a $5 \%$ share of the reducer.

It can be assumed that carbon monoxide was a gaseous phase and it was produced according to the following reaction:

$$
2 \mathrm{FeO} \cdot \mathrm{SiO}_{2}+2 \mathrm{C}=2 \mathrm{Fe}+\mathrm{SiO}_{2}+2 \mathrm{CO}
$$

The reaction is supported by the fact that both in original slag blocks and experimental samples iron precipitates were arranged in a form of nets that surrounded the sections of gas cavities - potential places where slag reduction occurred. Such a process could take place only when the volume of solidifying slag was considerate.

Obtained results constituted another piece of evidence supporting the theses connected with the concept of the surface of free solidification. Both the macrostructure of the surface of numerous slag blocks and the effects visible in their cross sections suggest that the blocks were formed by means of solidification of liquid slag that filled the pit and not by means of a gradual slag flow. The segregation of elements and phases visible in the cross section constituted the first piece of evidence. It proved that the slag block was formed by means of a solidification of a large amount of liquid slag that flowed down into the pit. The second piece of evidence consists in the effect of secondary iron reduction. Additional arguments supporting the view consist in the presentation of the macrostructure of the blocks and their form. 


\section{SUMMARY}

Ancient smelters' abilities were noticed already in 1965 by a metallurgist from Kraków, professor Mieczysław Radwan. Iron bloom was a basic product of the smelting process. It was a semi-finished product that was then used to make everyday objects. There was also a side product - a slag block. These two products of the bloomery furnace became unrivalled models for researchers who were only able to obtain lumps of iron slag conglomerate instead of an iron bloom and a slag block.

After 40 years of futile attempts to recreate the furnace and the smelting process a new archaeological concept was presented. It was a result of a detailed analysis of basic archaeological pieces of evidence such as the pit and the slag block. The validity of this concept was reviewed positively by investigating crystal structure and the segregation of phases in the cross section of the blocks. The crux of the concept consists in a total tapping of slag from the shaft into the pit in the final stage of the bloomery process. This allowed the smelter to obtain a purified iron bloom. It still remains a mystery how the smelter managed to do it. Other questions come to mind as well:

- Was there one or more air inlets in the shaft and where were they located?

- Was the number of inlets increased during the melt in order to regulate the supply of air?

- Where did the fractions of reduced iron gather? How did they form an iron bloom?

- How did the iron bloom remain in the shaft during the flow of slag?

- Where and how did the slag gather during the process? Did tapping proceed automatically thanks to the structure of the furnace or did the smelter trigger it?

- What was the organization of the technological process? What was the charge used?

- What were its properties, proportions of ore, charcoal? What were the thermal and time parameters of the process and the related actions undertaken by the smelter?

These questions should become the focus of further experimental research. The research should take into consideration the results obtained thanks to the observation of the surface of free solidification on slag blocks and the properties of the pit.

The expected results concerning the changes in the structure of the furnace and the process itself will have a universal influence on the experimental research into ancient metallurgy in the central and northern archaeological area - area where bloomery furnaces were commonly used in the ancient times.

\section{REFERENCES}

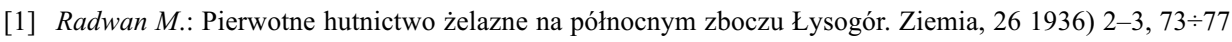

[2] Radwan M.: Z dziejów wytopu. Hutnik, 9 (1937) 6, 320 $\div 327$

[3] Jira J.A.: Osada razu provincjalne rimskeho v Podbabe a v Bubenci. Časopis společnosti v českych, t. II, Praha, 1910 
[4] Różański W: Badania metaloznawcze fragmentów żelaznych pochodzacych ze stanowiska w Jeleniowie, powiat Opatów. Kwartalnik Historii Kultury Materialnej, 8 (1960) 4, 565 567

[5] Biborski M., Kaczanowski P., Kędzierski Z., Stępiński J.: Proceedings Archeometallurgy in Europe. Milan, (2003) $1,97 \div 107$

[6] Radwan M.: Konferencja metalurgów i metaloznawców z archeologami i historykami. Kwartalnik Historii Nauki i Techniki, 1 (1956), 452 4463

[7] Radwan M.: Konferencja sprawozdawcza Zespołu Historii Techniki Hutniczej i Odlewniczej. Kwartalnik Historii Nauki i Techniki, 3 (1958), 491 $\div 504$

[8] Radwan M., Bielenin K.: Badania nad starożytnym hutnictwem żelaza w rejonie Gór Świętokrzyskich

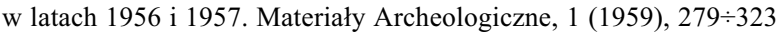

[9] Bielenin K.: Starożytne górnictwo i hutnictwo żelaza w Górach Świętokrzyskich, wyd. 2. KTN, Kielce, 1992

[10] Bielenin K.: Erkundung archäologischen Objekte mit modernen Technischen und naturwissenschaftlichen

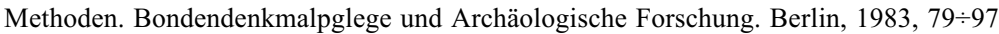

[11] Bielenin K.: Dymarki świętokrzyskie. WA, 39 (1974) 2, 123 129

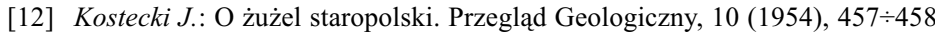

[13] Orzechowski Sz.: Metallurgical station Pokrzywnica 1, a contribution to the issue of unorganised bloomery sites in the Holy Cross Mountains. Early Ironworking in Europe. Archaeology and experiment. International Conference, ed. P. and S. Crew, Plas Tan y Bwlch. Snowdonia National Park Study Centre, 1997, 25

[14] Orzechowski Sz.: Wyniki najnowszych badań na stanowiskach osadniczych i produkcyjnych świętokrzyskiego centrum hutniczego, w: 50 lat badań nad starożytnym hutnictwem świętokrzyskim. Archeolo-

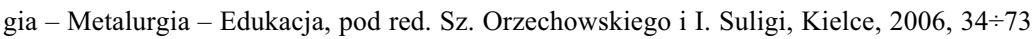

[15] Woyda S.: Mazowieckie Centrum Metalurgiczne z młodszego okresu przedrzymskiego i okresu wpływów, w: Hutnictwo świętokrzyskie i inne centra i ośrodki starożytnej metalurgii żelaza na ziemiach polskich, KTN, Kielce, 2002, 134

[16] Wegewitz W.: Ein Rennofen aus einer Siedlung der älteren Römerzeit in Scharnbeck Kr.Harburg /Nachrich-

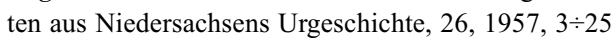

[17] Bielenin K.: Dymarski piec szybowy zagłębiony typu kotlinkowego w Europie Starożytnej. Materiały Ar-

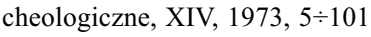

[18] Bielenin K.: Kilka dalszych uwag dotyczących starożytnego hutnictwa świętokrzyskiego, w: Hutnictwo świętokrzyskie i inne centra i ośrodki starożytnej metalurgii żelaza na ziemiach polskich. KTN, Kielce, $2002,11 \div 25$

[19] Espelund A.: Luppenstudien in Norwegen, Archeologia Austriaca, 1998-1999, 82

[20] Bielenin K.: 50 lat badań nad starożytnym hutnictwem świętokrzyskim. Archeologia - Metalurgia -

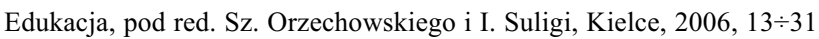

[21] Voigt T:: Die Rennofen von Riestad Kr. Sangerhausen, w: Jahreschrift für Mitteldeutche Urgeschichte, $1964,48,219 \div 308$

[22] Dušek S.: Eisenschmelzöfen einer germanischen Siedlung bei Gera Tinz, w: Alt Thüringen, IX, 1967, $95 \div 183$

[23] Lüders E.: Zum Stand der Erforschung Ur und Frühgeschichtl. Eisenerzeugung im Kreis Perleberg, Infor-

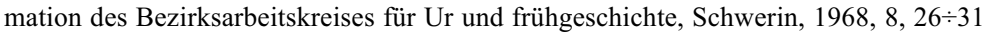

[24] Bielenin K.: Rennfeurofen mit eingetieften Hard und seine Formrn in Polen, Offa Bd, 40, 47 $\div 61$

[25] Hajen H.: "Isrnbarg" Ein Eisenverhüttungsplatz in Streckermor gemeinde Hatten Lkkrt Oldenburg, Oldenburger Jahrbuch, 67, 1963, 133 $\div 173$

[26] Dehnke R.: Ein Siedlungs und Eisenverhüttung platz der spätrömischen Kaiserzeit von westerholz Kr. Rotenburg/Wünne, w: Nachrischten aus Niedersaschsens Urgeschichte, 1967, 36, 133 136 
[27] Dehnke R.: Ein Siedlungs und Eisenwerhüttungs platz der spätrömischen Kaiserzeit w: Nachrischten aus Niedersaschsens Urgeschichte, 39, 1970, 268 $\div 274$

[28] Vöss O.: Iron furnaces in Danmark w: Archeology of iron 1967-1987 Sympozjum Liblice, 1983, 151 187

[29] Jöns H.: Frühe Eisen verhuttung in Joldelund kr. Norfriesland Universitätsforschungen zur prähistorischen Archaologie, 1977

[30] Bielenin K.: Recenzja, H. Jöns, Frühe Eisenverhüttung in Joldelund Kr. Nordfriesland, Ein Beitrag zur Siedlungs und Technik Geschichte Schleswig Holsteins w: Prehistorische Zeitschrift B. 75 H 2 2000, 258 $\div 254$

[31] Spazier I.: Das germanische Eisenverhüttungszentrum Wolkenberg Niederlausitz und andere germanische Schmelzplatze w: Aufschluss 48, 1997, 293 $\div 303$

[32] Spazier I.: Das germanische Eisenverhüttungszentrum Wolkenberg in der Niederlausitz/ Südbrandenburg mit über 1000 Rennöfen. w: Arbeita und Arbeits Vorschungsberichte zur Sächsiechen Bodendenkmalpflege, 2000, 42, 317 $\div 331$

[33] Wetzel G.: Einige Beispiele zur Germanischen Eisenerzeugung zwischenSchwarzen Elster und Naise w:Archeolog. Etnographische zeitschrift 37, 1996, 365 $\div 373$

[34] Wetzel G.: Siedlungs geschichte in Kreise Hoyeswerda bis zum Mitelalter w: Geschichte und gesehichten aus Dörfern und Stadten, 2, 1997, 2 $\div 32$

[35] Bidzila W.I.: Z historii czornoj mietałłurgii karpatskogo uzgiria rubieży naszej ery. Archeologia, Kiev, 1964, 10

[36] Pankov S.W.: Metalugija żeleza u plemion wostocznego Wolynia (Żytomiersczyzny) rubieża pierwoj połowiny I tys. 1. n. e., Sovietska Archeologia, 1992, I, 192 $\div 197$

[37] Bielenin K.: Starożytne hutnictwo żelaza w rejonie Starachowic i Doliny rzeki Kamiennej, w: Wybrane

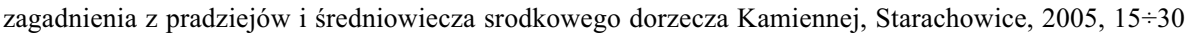

[38] Holewiński S.: Wstępne badania starożytnych żużli hutniczych skupionych na niektórych terenach Polski. Archiwum Hutnictwa, 1, 1956, 3, 251-282

[39] Suliga I, Karbowniczek M., Góra M., Orzechowski Sz.: Studia porównawcze żużli dymarskich i miseczkowatych z pokrzywnicy, sta.1, gm. Pawłów, woj. świętokrzyskie, w: Hutnictwo świętokrzyskie i inne centra i ośrodki starożytnej metalurgii żelaza na ziemiach polskich. KTN, Kielce, 2002, 183 $\div 190$

[40] Neumann B.: Die älteste Vrfahren der Erzeugung Technischen Eis w: Freiberger Forschungshefte, 1954, D.6 Berlin

[41] Radwan M.: Dotychczasowe próby odtwarzania procesu metalurgicznego w dymarkach typu świę-

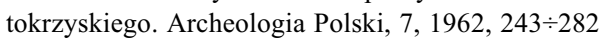

[42] Radwan M., Pleiner R.: Próbne wytopy żelaza w dymarkach typu świętokrzyskiego. Kwartalnik Historii Nauki i Techniki, 7, 1962, 589 $\div 590$

[43] Radwan M., Pleiner R.: Polsko-czechosłowackie doświadczenia wytopu żelaza w dymarkach z okresu

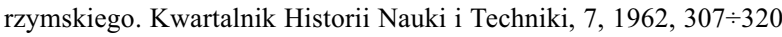

[44] Radwan M.: Konferencja sprawozdawcza Zespołu Historii Polskiej Techniki Hutniczej i Odlewniczej Polskiej Akademii Nauk, KHNiT, 3, 1958, 3, 491 $\div 504$

[45] Radwan M.: Konferencja sprawozdawcza Zespołu Historii Polskiej Techniki Hutniczej i Odlewniczej, KHNiT, 4, 1959, 2, 387 $\div 393$

[46] Radwan M.: Konferencja sprawozdawcza Zespołu Historii Polskiej Techniki Hutniczej i Odlewniczej,

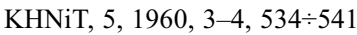

[47] Radwan M.: Z prac Zespołu Historii Polskiej Techniki Hutniczej i Odlewniczej, KHNiT, R. 6, 1961nr 1, s. $178 \div 179$

[48] Radwan M.: Dotychczasowe próby odtworzenia procesu metalurgicznego w dymarkach typu świę-

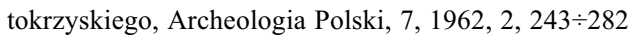

[49] Radwan M.: Dalsze próbne wytopy w piecykach dymarskich typu świętokrzyskiego, KHNiT, 9, 1964, 1, $158 ; 3-4,365 \div 373$ 
[50] Radwan M.: Konferencja sprawozdawcza Zespołu Historii Polskiej Techniki Hutniczej i Odlewniczej, KHNiT, 9, 1964, 3-4, 446 $\div 448$

[51] Radwan M.: Dalsze próbne wytopy żelaza w dymarkach. KHNiT, 10, 1965, 4, 670

[52] Radwan M.: Nowe próbne wytopy żelaza w Słupi Nowej. KHNiT, 10, 1965, 1-2, 227 228

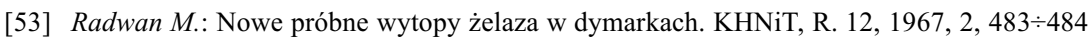

[54] Suliga I.: Dotychczasowe próby rekonstrukcji starożytnego procesu metalurgicznego w kotlinkowych piecach dymarskich z regionu świętokrzyskiego, w: 50 lat badań nad starożytnym hutnictwem świętokrzyskim. Archeologia - Metalurgia - Edukacja, pod red. Sz. Orzechowskiego i I. Suligi, Kielce, 2006, $163 \div 173$

[55] Różański W: Sprawozdanie z doświadczalnych wytopów żelaza przeprowadzonych podczas obozu

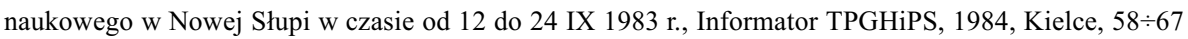

[56] Leineweber R.,Lychatz B.: Versuchen in Rennofen-Eine Bilanz Jahresschrift für itt ldeutsche Vorgeschichte $80,1986,263 \div 304$

[57] Lychatz B., Janke D.: Experimentalle Simulation der frühen Eisenverhüttung w: Arbeits und Forschungsberichte zur Sächsisch, Bodendenkmalpflege, 2000, 3.42,28T $\div 306$

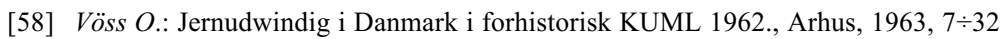

[59] Barbe H., Esbjerd R., Thomsen V.: Rekonstruktionsversuche zur Frühgeschichtlichen Eisengevinnung, Offa Bd, 1983, $153 \div 156$

[60] Pleiner R.: Experiment w Archeologii, Pamatky Archeologicke, LII, 1961, 616 622

[61] Pawliska V.: Umris geschichte der metalle Inst. Der Metallurgie der Technischen Universitat, Berlin

[62] Andrieux Ph.: Prolegomenes a une etude traceologique sur strucyures d'elaboration thermique et les parois Argilo-Sableuses, Thèse, Universite de Franche-Comte, 1990

[63] Nikulka F.: Frühe Eisenverhüttung und experimenteller Nachvolzug Eine Analyse bisheriger Versuche, Experimentelle Archäologie Bilanz 1994 w: Archäologische Mitteilungen aus Nordwestdeutschland Beiheft 8, 1995, 255 $\div 310$

[64] Reyman T: Na śladach rudnic Igołomska fabricae ferri z okresu rzymskiego, Z otchłani wieków, 21, 1952, $119 \div 128$

[65] Bielenin K.: Frühgeschichtliches Bergbau- und Eisenhüttenwesen im Świętokrzyskie-Gebirge, (w:) Eisenverhüttung vor 2000 Jahren. Archäologische Forschungen in der Volksrepublik Polen, Düsseldorf, 1977, $11 \div 26$

[66] Lück A.: Zur vor und frühgeschichtlichen Eisenverhüttung in Siegerland, w: Eisen Archologie Eisenerzberg-

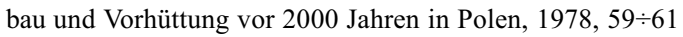

[67] Pleiner R.: Experimental Smelting of Steel nearly medial Furnaces, Pamatky Archeologicke, LX, $458 \div 487$

[68] Novaki G.: Archäologische Denkmäller der Eisenverhüttung in Nordwest Ungarn aus dem X-XII Jhd.Acta Archeolog.Hungaricum, 1969, 299 $\div 331$

[69] Bielenin K.: Kilka dalszych uwag dotyczących starożytnego hutnictwa świętokrzyskiego, w: Hutnictwo świętokrzyskie i inne centra i ośrodki starożytnej metalurgii żelaza na ziemiach polskich, KTN, Kielce, $2002,11 \div 25$

[70] Bielenin K.: Żużel żelazny jako źródło archeologiczne w relacji żużel - typ pieca dymarskiego i odwrotnie, PMMAE, 1978, 25, 53 64

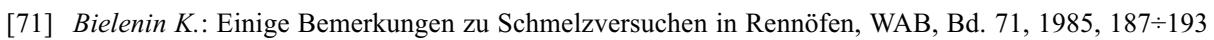

[72] Einige Bemerkungen zu den Rennofenschlacken der Schlackengrubenöfen, (w:) ,...und sie formten das Eisen". Ur-, frügeschichtliche und mittelalterliche Eisengewinnung und-verarbeitung. Internacionales ÖGUF-Symposion, Linz-Freinberg, 27.-30.10.1998, AAustr., Beih. 82-83, s. 523 $\div 528$

[73] Bielenin K.: Kloc żużla dymarskiego z Boleszyna. Uwagi o znaczeniu badań powierzchni kloców żużla dymarskiego, MA, t. 35 , s. $189 \div 198$ 
[74] Suliga I.: Próba metalurgicznej weryfikacji koncepcji archeologicznej K. Bielenina ,powierzchni swobodnego krzepnięcia” starożytnych kloców żużlowych, na podstawie kloca z Kowalkowic, gm. Waśniów, Materialy Archeologiczne, 26, 2006, 267 $\div 272$

[75] Suliga I., Kargul T: Efekt redukcji wtórnej w starożytnych żużlach dymarskich, Hutnik-Wiadomości Hutnicze, $74,2007,615 \div 622$

Received

November 2008 